\title{
COMPARATIVE STUDIES OF LUMINESCENCE IN COPEPODS AND OTHER PELAGIC MARINE ANIMALS*
}

\author{
By G. L. Clarke, R. J. Conover, C. N. David and \\ J. A. C. NiCOL \\ Harvard University, Woods Hole Oceanographic Institution \\ and the Plymouth Laboratory
}

(2 Plates and Text-figs. I-7)

Many marine copepods are luminescent. Some secrete a luminous material, and there is evidence that they produce light internally as well (Vanhöffen, I895). Using photo-electric recording, David \& Conover (I96I) investigated the flashing of Metridia lucens Boeck and described its luminous responses and behaviour. In the present investigations the luminescence of various other copepods is compared with that of M. lucens, and some measurements of light-emission in other animals are presented to illustrate differences in the nature of luminescent discharges among certain pelagic species. The positions of the luminescent glands have been determined in several species of copepods, and histological studies have been made. The habits of $M$. lucens and the literature dealing with luminescence in copepods have been reviewed previously (David \& Conover, I96I). Measurements and records of luminous flashing made with underwater photometers in the Atlantic and in the Mediterranean have been reported by Clarke \& Hubbard (1959) and Clarke \& Breslau, (1959, 1960). The relations between the intensity of bioluminescence, the strength of daylight penetrating from the surface, and the photosensitivities of animals in the sea are discussed by Clarke \& Denton (I962).

\section{MATERIALS AND METHODS}

The majority of copepods and other animals examined in this investigation was collected during cruise 64 of R.V. 'Crawford' (Woods Hole Oceanographic Institution), 24-30 July, 196I, from stations as follows: Jy I, $38^{\circ} 42^{\prime} \mathrm{N}$., $60^{\circ} 52^{\prime} \mathrm{W}$.; Jy 2, $37^{\circ} 28^{\prime} \mathrm{N}$., $69^{\circ} \mathrm{O} \cdot 2^{\prime} \mathrm{W}$.; Jy $3,39^{\circ} 58^{\prime} \mathrm{N}$., $66^{\circ} 30^{\prime} \mathrm{W}$.; Jy $4,4 \mathrm{I}^{\circ} 30^{\prime} \mathrm{N}$., $65^{\circ} \mathrm{O} \cdot 2^{\prime} \mathrm{W}$.; Jy $5,43^{\circ} 22^{\prime} \mathrm{N}$., $67^{\circ} 42^{\prime} \mathrm{W}$. A log of pertinent information regarding these stations is given in the Appendix (p. 564). Further supplies of copepods were collected by R.V. 'Crawford' at $39^{\circ} 40^{\prime}$ N., $69^{\circ} 48^{\prime}$ W., 05.00-06.00 h, 7 September 196I. A collection of Metridia spp. was obtained from the Gulf of Maine by the M.V. 'Captain Bill III' (Woods Hole), 29 June 196I. Some specimens of M. lucens were collected at Millport at intervals and sent to the Plymouth laboratory.

* Contribution no. 1285 from the Woods Hole Oceanographic Institution. Research supported by National Science Foundation Grants 8913, 8339 and 16355 . 
Collections were made with open nets $\frac{3}{4}$ or I m diameter, made of no. $\infty$ or oo nylon, lowered obliquely to maximum depth, towed about $\frac{1}{2}-\mathrm{I} h$, and returned to surface (Appendix, p. 564). Copepods were kept under refrigeration on shipboard and in the laboratory, and were removed immediately prior to examination (see Conover, I960; and David \& Conover, I96I, for details of culture procedure). Other animals were examined immediately after capture.

Copepods flash only when stimulated. For electrical excitation, short bursts of a.c. $(60 \mathrm{cyc} / \mathrm{sec}$ ) or condenser shocks (up to $20 \mathrm{~V}, 0.5 \mu \mathrm{F}$ ) were used. The animals were held in small chambers of wax or lucite (polymethyl methacrylate), containing platinum or carbon electrodes.

Procedures used for mechanical or tactile stimulation were these. A copepod, in sea water, was dropped upon a piece of filter-paper, or it was placed in a sintered glass funnel, the water from which was removed by a vacuum pump. With either procedure the copepod usually flashed brilliantly when the water was withdrawn. Lucite chamber I consisted of a central well, semicircular in cross-section, $4 \times 4.5 \times 5.5 \mathrm{~cm}$, connected with two smaller electrode wells by salt-agar plugs (see David \& Conover, 196I, fig. I). Lucite chamber 2 contained a cylindrical well, $\mathrm{I} \times \mathrm{I} \mathrm{cm}$, connected with two large electrode pools by cotton and sea-water plugs (Chang, I954, fig. I). Wax chamber 3 contained a slit $3 \mathrm{~mm}$ wide $\times 3 \mathrm{~mm}$ deep, with a short central area separated from lateral electrode areas by cotton and sea-water plugs.

Luminous flashes were detected by a photomultiplier tube (E.M.I. type no. 6095 B) at a distance of $15 \mathrm{~cm}$. The tube was connected to a cathode-ray oscilloscope through d.c. amplifier, and vertical excursions of the upper beam were photographed on moving paper. Other records were obtained with sweeps triggered by the stimulating pulse. The voltage of the photomultiplier was held constant and sensitivity of the oscilloscope was varied. A daily check of sensitivity was made with a stable light emitter (button containing radioactivated phosphor), and the sensitivity of the photomultiplier was calibrated against a substandard lamp (Clarke \& Wertheim, 1956).

In the laboratory, the temperature of the room where observations were made was $14^{\circ} \mathrm{C}$. At sea, laboratory temperatures lay mostly in the range $10^{\circ}-20^{\circ} \mathrm{C}$.

Harvey $(1926 b)$ noted that the luminescent glands of some copepods are fluorescent. This feature was utilized to assist in mapping out the location of the luminescent glands in those species in which they are fluorescent, and to photograph them. Ultraviolet sources were: Osram HBO 200; Blak-ray long-wave u.v. (Ultra-violet Products, Inc.); American Optical Co. Mercury Vapor lamp model 760 ; G.E. lamp AH 4; Philips lamp ME/D Compact Source. Excitation filters used were Chance OX I, Corning 5113, 5850, 9863, Wratten I8 A; barrier filters were Chance OB2 plus OGr 2, Corning Noviol A and Yellow Shade.

Histological methods are dealt with below (p. 552).

\section{OBSERVATIONS ON COPEPODA}

\section{LUMINOUS RESPONSES}

\section{Whole animals}

The following species, taken in our tows, were found to be luminous: Metridia lucens Boeck, M. longa (Lubbock), M. princeps Giesbrecht, Pleuromamma robusta (F. Dahl), P. xiphias (Giesbrecht), Heterorhabdus norvegicus (Boeck), H. robustus Farran, Heterostylites longicornis (Giesbrecht), Lucicutia grandis (Giesbrecht), Hemirhabdus grimaldii Richard, Disseta palumboi Gies- 
brecht, Euaugaptilus magnus (Wolfenden) and Centraugaptilus horridus (Farran). The genera Heterostylites, Hemirhabdus, Disseta, Euaugaptilus and Centraugaptilus have not been described previously as luminous. Only one or a few individuals of some of these species were available for study. Many $M$. lucens, $M$. longa and $P$. robusta were obtained and these were used in the majority of experiments.

When stimulated electrically or mechanically, luminescent copepods discharge a luminous secretion; at the same time they make a spasmodic movement of abdomen and appendages and, if free to do so, they dart away. All species examined possess several or many luminescent glands; M. lucens, for example, has glands on the head, middle thorax and urosome (details on p. 549). In a fresh animal, material may be discharged simultaneously or nearly simultaneously from all these glands; several patches of glowing secretion can be seen in the water and these become agitated and diffused when the animal moves. During the course of repeated stimulation, flashes become weak and some glands cease discharging before others. A luminous response may be a complex event consisting of several luminous discharges with changing temporal and spatial characteristics. Glands also luminesce within the animal; if the animal moves, these spots of light move about correspondingly, sometimes becoming exposed to view and at other times becoming hidden by the animal's body.

\section{Electrical stimulation}

With brief pulses of a.c. ( $60 \mathrm{~V})$, copepods emit irregular flashes having durations of less than a second to $7 \mathrm{sec}$ on the oscilloscope records (Table I). Durations of responses, estimated visually, are: $3-22 \mathrm{sec}$ for $M$. longa; 3-37 sec for $M$. lucens; $2-16 \mathrm{sec}$ for $P$. robusta. Maximal intensities are reached in $0.03-0.8 \mathrm{sec}$, often within $0 . \mathrm{I}$ sec. Intensities (all species) range from $0.02 \times 10^{-5}$ to $9.4 \times 10^{-5} \mu \mathrm{W} / \mathrm{cm}^{2}$ receptor surface at $15 \mathrm{~cm}$ distance $\left(0.0045 \times\right.$ IO $^{-2}$ to $2.015 \times \mathrm{IO}^{-2} \mu \mathrm{W} / \mathrm{cm}^{2}$ at $\left.\mathrm{I} \mathrm{cm}\right)$. The following observations refer especially to Metridia and Pleuromamma. Luminescent responses appear as quick flashes, prolonged glows, or combinations thereof (Text-fig. IA-C, E, $\mathrm{G}-\mathrm{M}, \mathrm{O}-\mathrm{Q})$. Flashes are irregular and show one or several major peaks and often several smaller peaks, or a quick flash may be followed by a glow-response. The maximum is followed by a protracted decay period, longer in glowresponses. With repetitive stimulation the intensities of consecutive responses vary in a random manner, but there is a general tendency for the responses of a series to become weaker and finally cease, as photogeny becomes progressively exhausted (Text-fig. IK-M).

With single condenser discharges $(0.5 \mu \mathrm{F}, 20 \mathrm{~V}$, chamber 3$)$, the luminescent responses tend to be simpler in form. Often the response is a brief flash with quick rise and slower decay (Text-figs. IH, N; 2). Maximum is reached in about $0.03 \mathrm{sec}$ and decay occurs more slowly $(90 \%$ decay in $0.5 \mathrm{sec}$, 
TABLE 1. FLASH CHARACTERISTICS OF COPEPODS UNDER ELECTRICAL STIMULATION

\begin{tabular}{ll}
\multicolumn{1}{c}{ Species } & \multicolumn{1}{c}{ Stimulus } \\
Metridia lucens & a.c. \\
M. lucens & Condenser shocks \\
M. longa & a.c. \\
M. longa & Condenser shocks \\
M. princeps & a.c. \\
Pleuromamma spp. & Condenser shocks \\
P. robusta & a.c. \\
P. xiphias & a.c. \\
Lucicutia grandis & a.c. \\
Euaugaptilus magnus & a.c. \\
Heterorhabdus spp. & a.c. \\
Heterorhabdus spp. & Condenser shocks \\
Heterostylites longicornis & a.c.
\end{tabular}

$\begin{gathered}\text { Duration } \\ (\mathrm{sec})\end{gathered}$
$0 \cdot 1-5 \cdot 5$
0.5
$0 \cdot 5-6 \cdot 3$
$0.3-\mathrm{II}$
$\mathrm{I} \cdot 6-7$
$0 \cdot 2-0 \cdot 3$
$0 \cdot 2-2 \cdot 5$
$0 \cdot 3-6 \cdot \mathrm{I}$
$0 \cdot 2-2$
$0.4-\mathrm{I} \cdot 4$
0.3
3

To maximum
$(\mathrm{sec})$
$0.03-0.83$
0.03
$0.06-0.33$
0.048
$0.1-0.9$
$0.06-0.11$
$0.04-0.8$
-
-
-

$90 \%$ decay
(sec)
$0.07-4 \cdot 1$
0.5
To $3 \mathrm{sec}$
-
-
0.01-1.5
To 3.6
-
-

Luminescent intensity,

$\mathrm{W} / \mathrm{cm}^{2}$ receptor

Temperature

$$
\text { at } 15 \mathrm{~cm}
$$

$0.02-0.77 \times 10^{-5}$

$0.13-2.58 \times 10^{-5}$

$0.07-1.5 \times 10^{-5}$

To $4.3 \times 10^{-5}$

$0.17-9.4 \times 10^{-6}$

$0.12 \times 10^{-3}$

$0.0 \mathrm{I}-0.05 \times 10^{-5}$

$0.34-\mathrm{I} \cdot 29 \times 10^{-3}$

$0.12-0.70 \times 10^{-5}$

$0.66 \times 10^{-5}$

$0.16-0.42 \times 10^{-5}$

$0.3-0.77 \times 10^{-5}$

I4

I4

I4

$10-20$

I4

10-15

IO- 20

IO-20

10-15

$10-20$
$10-20$ 


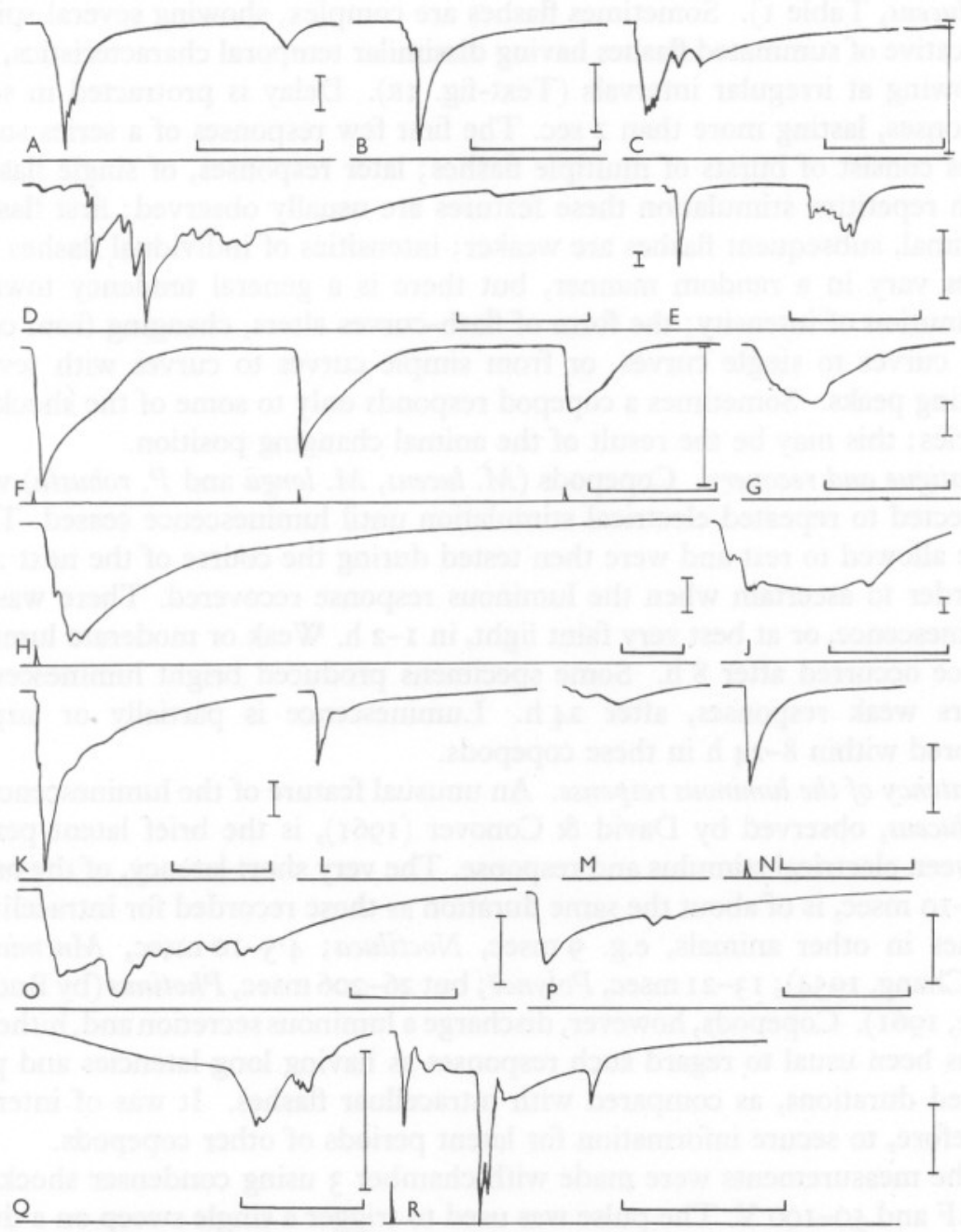

Text-fig. I. Tracings of oscilloscope records of the luminous flashes of copepods. Recordings on moving paper were made of vertical excursions of the oscilloscope beams. Deflexions downwards of the upper line represent luminous responses. Electrical signal, when used, indicated on lower line. The horizontal bar represents the time scale, equivalent to I sec for all records except $\mathrm{H}$, where it is equal to $\mathrm{O}^{\mathrm{I}} \mathrm{I}$ sec. Vertical bar, to the right, shows light intensity and is equivalent to $\mathrm{I} \times \mathrm{IO}^{-6} \mu \mathrm{W} / \mathrm{cm}^{2}$ at $15 \mathrm{~cm}$ distance. Temperature $14^{\circ} \mathrm{C}$. A, Metridia longa, quick flashes to a short pulse of a.c. B, M. lucens, quick flash to a short pulse of a.c. C, Heterostylites longicornis, flash following a short pulse of a.c. D, Flashing of $M$. lucens after mechanical stimulation. E, Pleuromamma robusta, complex flashes following a short pulse of a.c. F, Flashes from the tail of $M$. longa in response to a series of condenser shocks. G, Heterorhabdus norvegicus, flash following a short pulse of a.c. $\mathrm{H}$, Luminous response of $M$. lucens to a condenser shock. J, M. longa, prolonged glow response following a short pulse of a.c. $\mathrm{K}, \mathrm{L}, \mathrm{M}$, Pleuromamma xiphias, flashes in response to a series of short a.c. pulses. N, R, Simple and complex flashes of M. lucens in response to condenser shocks. o, Euaugaptilus sp., prolonged glow with superposed flashes following a short burst of a.c. P, M. lucens, prolonged responses following a short pulse of a.c. Q, $M$. princeps, prolonged glow, with superposed short flash, following a short pulse of a.c. 
M. lucens, Table I). Sometimes flashes are complex, showing several spikes, indicative of summated flashes having dissimilar temporal characteristics, and following at irregular intervals (Text-fig. IR). Delay is protracted in some responses, lasting more than $2 \mathrm{sec}$. The first few responses of a series sometimes consist of bursts of multiple flashes; later responses, of single flashes. With repetitive stimulation these features are usually observed: first flash is maximal, subsequent flashes are weaker; intensities of individual flashes in a series vary in a random manner, but there is a general tendency towards diminution of intensity; the form of flash-curves alters, changing from complex curves to single curves, or from simple curves to curves with several shifting peaks. Sometimes a copepod responds only to some of the shocks in a series; this may be the result of the animal changing position.

Fatigue and recovery. Copepods ( $M$. lucens, $M$. longa and $P$. robusta) were subjected to repeated electrical stimulation until luminescence ceased. They were allowed to rest and were then tested during the course of the next $24 \mathrm{~h}$ in order to ascertain when the luminous response recovered. There was no luminescence, or at best very faint light, in $\mathrm{I}-2 \mathrm{~h}$. Weak or moderate luminescence occurred after $8 \mathrm{~h}$. Some specimens produced bright luminescence, others weak responses, after $24 \mathrm{~h}$. Luminescence is partially or largely restored within $8-24 \mathrm{~h}$ in these copepods.

Latency of the luminous response. An unusual feature of the luminescence of M. lucens, observed by David \& Conover (I96I), is the brief latent period between electrical stimulus and response. The very short latency, of the order of 8-10 msec, is of about the same duration as those recorded for intracellular flashes in other animals, e.g. $9 \mathrm{msec}$, Noctiluca; 4.5-10 msec, Mnemiopsis (by Chang, 1954); 13-21 msec, Polynoë; but 26-206 msec, Photinus (by Buck \& Case, 196I). Copepods, however, discharge a luminous secretion and, hitherto, it has been usual to regard such responses as having long latencies and prolonged durations, as compared with intracelluar flashes. It was of interest, therefore, to secure information for latent periods of other copepods.

The measurements were made with chamber 3 using condenser shocks of $0.5 \mu \mathrm{F}$ and $50-100 \mathrm{~V}$. The pulse was used to trigger a single sweep on a dualbeam oscilloscope, the screen of which could be photographed. The lower trace displayed the stimulus while the upper trace recorded the luminescence detected by the photomultiplier (Text-fig. 2).

The latent periods for nine species are tabulated in Table 2. The short latency has been observed again in M. lucens (ca. $8 \mathrm{msec}$ ) and also in two other species of the Metridiidae, viz. M. longa $(c a .9 \mathrm{msec})$ and Pleuromamma robusta (ca. $7 \mathrm{msec})\left(14^{\circ} \mathrm{C}\right)$. The reason for the slightly longer latency of $M$. longa may perhaps be associated with its greater size relative to $M$. lucens. (It seems to have a slightly higher threshold than $M$. lucens although the thresholds were not systematically measured.) The latency of an individual animal was usually consistent within the range in Table 2 for the first 

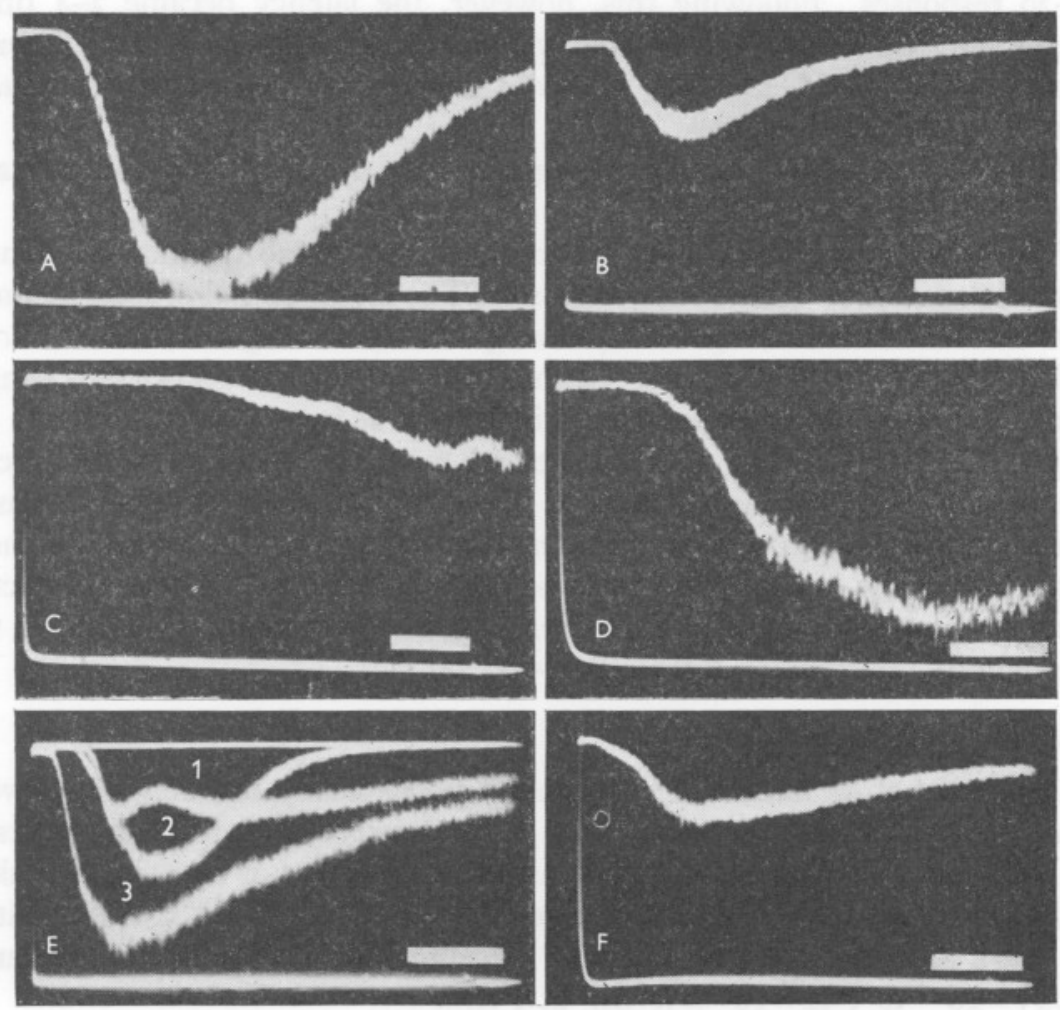

Text-fig. 2. Oscilloscope records (sweeps) of the luminous flashes of Heterorhabdidae. Responses to condenser shocks (signal on lower trace). Downward deflexion of upper trace represents a flash. Temp. $14^{\circ} \mathrm{C}$. Horizontal bar is time scale. A, Heterorhabdus robustus, time $200 \mathrm{msec}$. B, Heterorhabdus norvegicus, time $500 \mathrm{msec}$. c, Lucicutia grandis, time $200 \mathrm{msec}$. D, Hemirhabdus grimaldii, time $100 \mathrm{msec}$. E, Heterorhabdus robustus, three consecutive responses, note increment of second and third flashes, time $500 \mathrm{msec}$. F, Heterostylites longicornis, time $500 \mathrm{msec}$.

\section{TABLE 2. LATENCY OF LUMINOUS RESPONSES OF COPEPODS}

\begin{tabular}{lcc}
\multicolumn{1}{c}{ Species } & Range & Mean \\
Metridia lucens & $5 \cdot 1-36 \cdot 2$ & $8 \cdot 3$ \\
M. longa & $5 \cdot 3-25 \cdot 5$ & $9 \cdot 3$ \\
M. princeps & $24 \cdot 2-45 \cdot 0(3), 320$ & $\frac{-}{6 \cdot 9}$ \\
Pleuromamma robusta & $4 \cdot 2-10 \cdot 9$ & -1 \\
Lucicutia grandis & $133-15 \mathrm{I}(3)$ & - \\
Heterorhabdus robustus & $15 \cdot \mathrm{I}-\mathrm{I} 89$ & $46 \cdot 7$ \\
H. norvegicus & $9 \cdot 0-422$ & $65 \cdot 2$ \\
Hemirhabdus grimaldi & $31 \cdot 4, \mathrm{I} 33(2)$ & - \\
Heterostylites longicornis & $2 \mathrm{I} \cdot 2-48(7)$ & $32 \cdot 5$
\end{tabular}

(When only a few records were available, numbers examined are shown in parentheses.) 
I0-20 responses. Following this, however, the latency became 3-4 times longer and exhibited considerable variability as fatigue set in. Latency measurements of $M$. princeps, Lucicutia grandis and Hemirhabdus grimaldii were inadequate for analysis.

The latencies of anaesthetized $M$. longa (I/I000 tricaine methanesulphonate) increased from 9 to $30 \mathrm{msec}$.

Heterorhabdus norvegicus and $H$. robustus show some distinct differences from the species of Metridiidae examined. The latent period of fresh animals is far more variable and is generally from 4 to ro times longer than in M. lucens and $P$. robusta (Text-fig. 2A, B). Flashes of Heterorhabdus also show a simple form of facilitation upon repeated stimulation at intervals of about $0.1 \mathrm{sec}$ (Fig. 2F) and the kinetics of the flashes are markedly different from those of Metridia and Pleuromamma. Instead of the swift rise to maximal intensity generally observed in the latter genera, the species of Heterorhabdus more frequently show a slow, sloping increase in flash intensity. Protracted latencies were also encountered in Heterostylites longicornis, belonging to the same family (Heterorhabdidae) (Text-fig. 2F).

\section{Mechanical stimulation}

Specimens of $M$. lucens were stimulated mechanically, and recordings were made of the luminous responses. The animals usually responded by bouts of prolonged and complex flashing, occasionally with one or two single peaked flashes (Text-fig. ID). Durations range from $\mathrm{I} \cdot 4$ to $\mathrm{I} 2 \mathrm{sec}\left(\mathrm{I} 4^{\circ} \mathrm{C}\right)$. Intensities are $0.2 \times 10^{-5}$ to $14.4 \times 10^{-5} \mu \mathrm{W} / \mathrm{cm}^{2}$ receptor surface at $15 \mathrm{~cm}$ distance $\left(0.045 \times 10^{-2}\right.$ to $3.34 \times 10^{-2} \mu \mathrm{W} / \mathrm{cm}^{2}$ at $\left.\mathrm{I} \mathrm{cm}\right)$.

\section{Restricted areas}

Copepods (M. longa) were cut into two, some under anaesthesia (tricaine methanesulphonate, I/I000), others not, and records were made of the responses of each part, separately. Alternatively, part of a copepod was covered with opaque cotton (head or tail), and luminescence of the exposed region was recorded. Specimens were placed in chamber 3 and stimulated with condenser pulses $\left(0.5 \mu \mathrm{F}, 20 \mathrm{~V}\right.$; $\left.{ }_{4}^{\circ}{ }^{\circ} \mathrm{C}\right)$.

In records from these specimens, responses are simpler than in those from whole animals. Flashes usually show a single peak only, and have durations up to $2.5 \mathrm{sec}$ (Text-fig. IF). No consistent pattern is discernible during repetitive stimulation. The first flash may be the brightest; or there may be a progressive increase in the peaks of the first few flashes; or the intensities of the flashes in a series may vary at random. Intensities of the head glands or the tail glands of $M$. longa range from $0.02 \times 10^{-5}$ to $0.7 \times 10^{-5} \mu \mathrm{W} / \mathrm{cm}^{2}$ receptor surface at $15 \mathrm{~cm}$ distance. 


\section{POSITION OF LUMINESCENT GLANDS AND FLUORESCENCE}

Giesbrecht (1895) studied in some detail the distribution of luminescent glands in several copepods, and he observed that they appeared greenish yellow or yellow in fresh specimens, and Harvey (1926 b) observed fluorescence in luminous glands of copepods. In the present study all specimens were examined for fluorescence under ultra-violet light and, in most cases, they also were stimulated electrically under the microscope, using dark-field illumination. The glands of the Metridiidae (Metridia, Pleuromamma), Lucicutiidae (Lucicutia), and Augaptilidae (Euaugaptilus, Centraugaptilus) are fluorescent and this feature aided greatly in determining their position. A photograph showing the pattern of fluorescence of M. lucens is reproduced in Pl. I. The glands of the Heterorhabidae (Heterorhabdus, Heterostylites, Hemirhabdus, Disseta) are not fluorescent and therefore the location of luminescent organs could not be determined with the same degree of accuracy as in the first three families.

In the Metridiidae, the location of luminescent glands is constant within a species and differs from species to species. The patterns of distribution for two species, M. lucens and M. longa are compared in Text-fig. 3. Both species have the same distribution of glands in the urosome, namely a pair of glands opening just dorsal to the middle caudal bristle on each caudal ramus, and glands, perhaps paired, opening on the lateral posterior corner of the anal segments (cf. Text-fig. 3C, F). However, M. lucens has conspicuous glands opening laterally on the second thoracic segment (Text-fig. $3 \mathrm{~A}$ ), whereas M. longa has no glands on the thorax (Text-fig. 3E). The most striking differences between these species are shown by the glands on the head (see Text-fig. 3B, D). M. lucens always has ten glands, arranged in a distinctive pattern: three forming a triangle, on each side of the head just dorsal to the antenna; three in a row along the anterior edge of the carapace just dorsal to the rostrum; and a single gland centrally located (Text-fig. 3B). In M. longa the glands are clustered near the midline of the head as shown in Text-fig. 3D. The number of glands seems to vary from II to 15 , with the most probable number being 13 . Their number may be fixed, but due to their close proximity in some specimens one or two glands may have been obscured by others.

The distribution of glands in $M$. lucens does not agree entirely with the description given by David \& Conover (196I), who reported glands on the third and fourth thoracic segments and on all segments of the urosome. Probably these additional glands observed by David and Conover were nonluminous skin glands also seen in copepods by Giesbrecht (1895).

The few specimens of $M$. princeps examined showed still another pattern of fluoresence. In this species no gland was found in the caudal rami though large glands are present in the anal segment. There are single glands on either side of thoracic segments one and two in most specimens, but in one 
individual the left-hand gland was missing from segment two and was present instead on segment three, giving a curiously asymmetrical appearance to the fluorescence when viewed from above. A single gland or small cluster occurs at the most anterior margin of the head and two more fluorescent spots are seen at about the level of the mandibles on either side of the midline, at the shoulder between the dorsal and lateral body wall. Conspicuous glands also occur in the basipods of the first and second swimming legs.

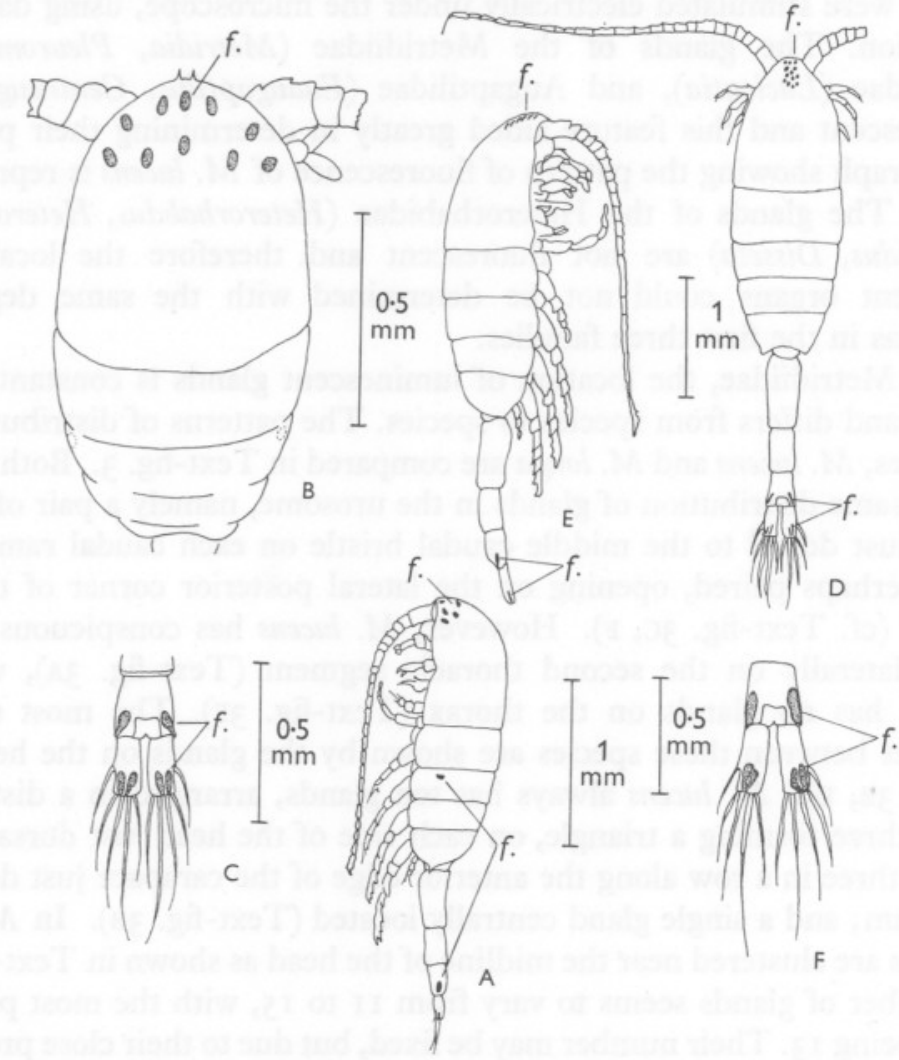

Text-fig. 3. Disposition of fluorescent glands in Metridia lucens (A-C) and M. longa (D-F). $M$. lucens. A, Lateral view of the left side of the whole animal; B, dorso-frontal view of head; C, dorsal view of anal segment and caudal rami. M. longa. D, Dorsal view of the whole animal; E, lateral view of the right side of the whole animal; F, dorsal view of anal segment and caudal rami. $f$, fluorescent areas.

The pattern of fluorescence for Pleuromamma robusta is shown in Textfig. $4 \mathrm{~A}-\mathrm{C}$. Typically, three glands occur just dorsal to the rostrum and another two in the posterior and lateral region of the head at the level of the mandibles (Text-fig. $4 \mathrm{~A}$ ), as in $M$. princeps. The curious pigment knob sometimes said to be the 'light organ' occurs either on the right or left-hand side of the first 
thoracic segment and is always balanced by a single luminescent gland on the side opposite. As observed by Giesbrecht (1895) this so-called light organ apparently has no function in the production of light and it shows no fluorescence. Double glands are also found on thoracic segment 2 (Text-fig. 4A and $\mathrm{B}$ ) and paired glands on the anal segment and caudal rami are also present (Text-fig. 4C).

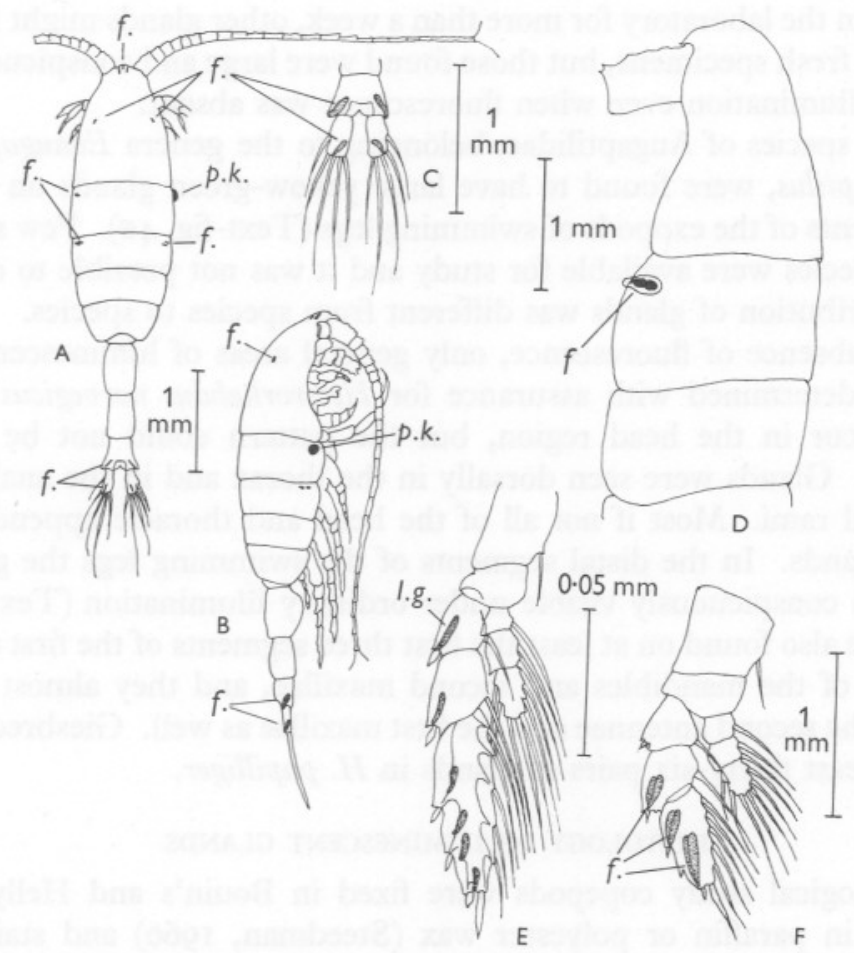

Text-fig. 4. Disposition of fluorescent and luminescent glands in several copepods. A-C, Fluorescent glands of Pleuromamma robusta: A, dorsal view of whole animal; B, lateral view, right side; C, dorsal view of anal segment and caudal rami. D, Anterior lateral view of Lucicutia grandis, showing position of fluorescent glands on the first thoracic segment. E, Position of fluorescent glands on the second swimming leg of Euaugaptilus magnus. F, Position of luminescent glands on the fourth swimming leg of Heterorhabdus norvegicus. $f$, fluorescent glands; l.g., luminescent glands; p.k., pigment knob.

A few Pleuromamma xiphias were also examined. The pattern was not very different from that observed in P. robusta except that only two glands were seen on the anterior portion of the head on either side of the crest near its base.

Both males and females of these five species were examined and no sexual dimorphism in number or location of luminescent glands was observed, 
although the asymmetrical urosome in the male $P$. xiphias results in a slightly different orientation of glands in the caudal rami and anal segment from that in the female.

Only a single pair of luminuos glands opening along the anterior ventral margin of the first thoracic segment was found in Lucicutia grandis (Textfig. 4D), although Giesbrecht (I895) described the position of ten glands for Lucicutia flavicornis. As the animals were not examined by us until after they had been in the laboratory for more than a week, other glands might have been present in fresh specimens, but those found were large and conspicuous under ordinary illumination even when fluorescence was absent.

Several species of Augaptilidae, belonging to the genera Euaugaptilus and Centraugaptilus, were found to have large yellow-green glands on the distal two segments of the exopods of swimming legs (Text-fig. 4E). Few specimens of each species were available for study and it was not possible to determine if the distribution of glands was different from species to species.

In the absence of fluorescence, only general areas of luminescent activity could be determined with assurance for Heterorhabdus norvegicus. Several glands occur in the head region, but the pattern could not be precisely discerned. Glands were seen dorsally in the thorax and in the anal segment and caudal rami. Most if not all of the head and thoracic appendages also contain glands. In the distal segments of the swimming legs the glands are sometimes conspicuously visible under ordinary illumination (Text-fig. 4F). Glands are also found on at least the first three segments of the first antennae, exopodite of the mandibles and second maxillae, and they almost certainly occur on the second antennae and the first maxillae as well. Giesbrecht (I895) found at least thirty-six pairs of glands in $H$. papilliger.

\section{HISTOLOGY OF LUMINESCENT GLANDS}

For histological study copepods were fixed in Bouin's and Helly's fluids, sectioned in paraffin or polyester wax (Steedman, 1960) and stained with Ehrlich's haematoxylin and eosin, Heidenhain-azan, modified Masson's trichrome (containing Bordeaux red and fast green or aniline blue) and Heidenhain's iron haematoxylin. Some attempts to stain sections with toluidine blue, neutral red, Bodian's silver and Jenner's blood stain were not particularly successful.

The following account is limited to the Metridiidae. The histology of the Heterorhabdidae presents special features which warrant a full investigation at another time.

Metridia longa. The luminous glands consist of elongate sacs lying beneath the hypodermis of the head, the third abdominal segment and the caudal furcae. The whole sac is spindle-shaped; for convenience of description two regions are distinguished, a distal ampullary half and a proximal stem. The distal half is pyriform, with a distal neck pointing towards the cuticle, and it is 
formed like an ampulla (Text-fig. 5). This region is about $65-70 \mu$ long and $20-25 \mu$ at its greatest diameter. At the neck the sac tapers to $5-6 \mu$. The lateral walls are thin, about $2 \mu$ in section, and basally the sac wall increases in thickness to about $4 \mu$. The base of the sac continues internally as a tapering cytoplasmic pyramid, about $70 \mu$ long.

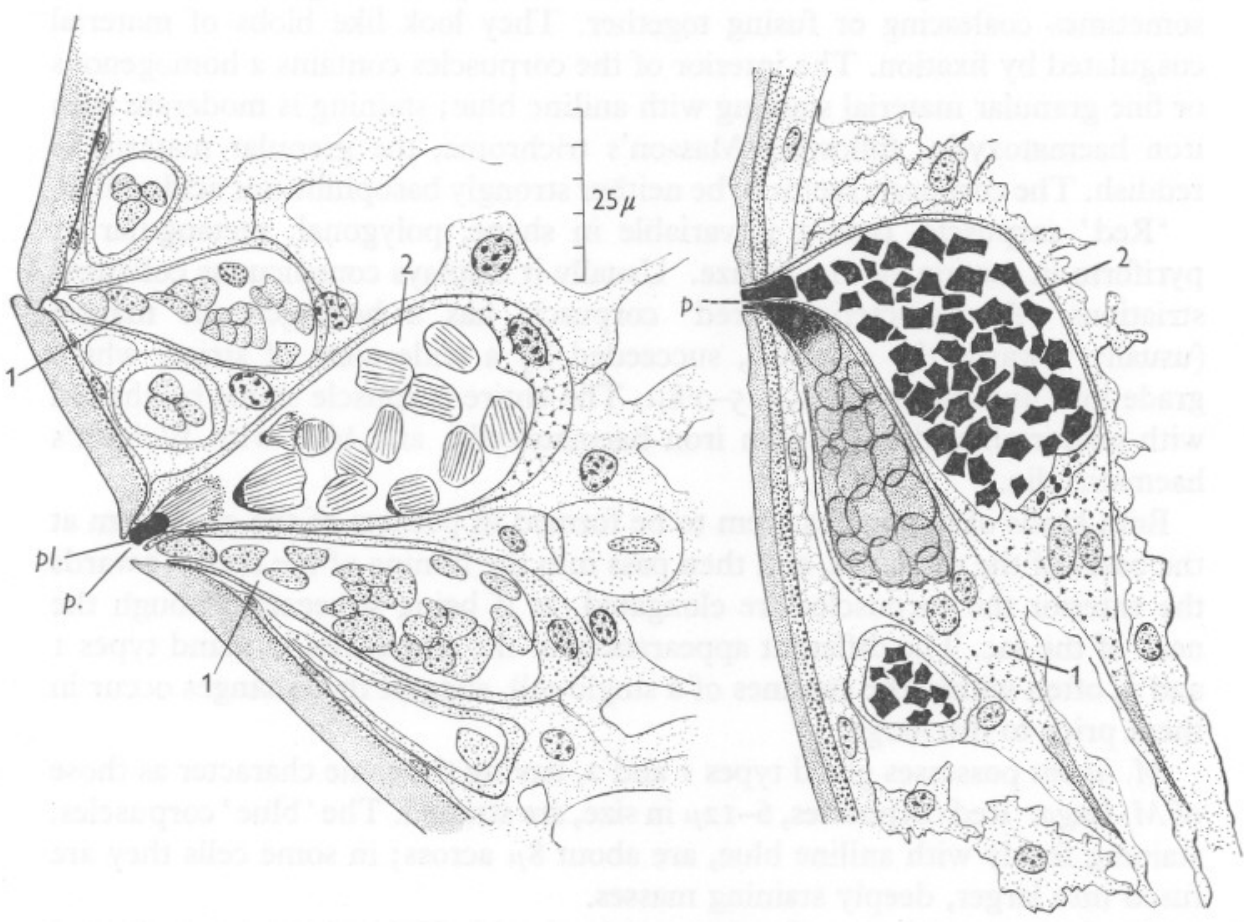

Text-fig. 5. Luminous glands in the head of Metridia longa. Left, longitudinal horizontal section, stained with Heidenhain-azan. Right, longitudinal vertical section stained with iron haematoxylin. p., Pore; $p l$, plug of secretory material in neck of gland cell; $\mathrm{I}, 2$, glands, types I and 2 respectively.

The cytoplasm of the lateral walls appears to contain fine corrugations or sinuous longitudinal striations, which stain poorly and which are at about the limit of microscopic resolution. In the base of the ampulla and in the basal stem the cytoplasm is granular and stains with haematoxylin. One or two nuclei (two seem to be usual) lie in the cytoplasm at the base of the distal half. The sacs are closely invested by stellate connective tissue cells of the mesoderm (Text-fig. 5; P1. II).

Each sac is a single large cell, in the ampullary distal half of which there is a large pyriform lumen containing conspicuous corpuscles (Pl. II). The contents of the sacs show differential staining with Heidenhain-azan; some 
sacs (gland type I) contain blue bodies staining with aniline blue ('blue' corpuscles); others (gland type 2), red bodies staining with azocarmine ('red' corpuscles). 'Blue' and 'red' sacs lie side by side in groups; a 'blue' and a 'red' sac open through the cuticle by a common aperture (pore, Pl. II).

'Blue' corpuscles, type I are very variable in shape, often subspherical or polyhedral, about $3-6 \mu$ in size. They are closely packed together in the sacs, sometimes coalescing or fusing together. They look like blobs of material coagulated by fixation. The interior of the corpuscles contains a homogenous or fine granular material staining with aniline blue; staining is moderate with iron haematoxylin; following Masson's trichrome, the granular material is reddish. The corpuscle seems to be neither strongly basophilic nor acidophilic.

'Red' corpuscle, type 2 is variable in shape, polygonal, rectangular or pyriform in section, 7-I I $\mu$ in size. Usually it displays conspicuous collateral striations. A characteristic 'red' corpuscle has a homogeneous margin (usually towards the exterior), succeeded by a wide zone of striae, which grade into lines of granules, $0.5-0.8 \mu$. The entire corpuscle stains bright red with azocarmine, densely with iron haematoxylin, and blue with Weigert's haematoxylin.

Both kinds of corpuscles seem to be formed in pockets of the cytoplasm at the bases of the ampullae, and then pass into the lumina of the sacs. Towards the exterior the corpuscles are elongated, as if being squeezed through the neck of the sac. The different appearances of the corpuscles in gland types I and 2 , often within the confines of a single cell, suggest that changes occur in them prior to discharge.

$M$. lucens possesses gland types I and 2, having the same character as those of $M$. longa. Red corpuscles, 6-12 $\mu$ in size, are striated. The 'blue' corpuscles, staining feebly with aniline blue, are about $8 \mu$ across; in some cells they are fused into larger, deeply staining masses.

Pleuromamma robusta. Sections, stained with Heidenhain-azan, showed luminescent glands in the head, which closely resembled those of M. longa. Gland types I and 2 were distinguishable. Gland type I contains small, blue-staining corpuscles $(c a .4 \mu)$. Gland type 2 possesses deeply staining red corpuscles, which are oval or ovoid in shape, and have longitudinal striations. These are $3-5 \mu \times 15-18 \mu$ in size. Other red corpuscles, apparently disintegrating, contain coarse reddish granules. The pore through the cuticle is $6 \mu$ in diameter, and contains a plug of striated red-staining material. The base of the cells contains two nuclei.

Gaussia princeps. One formalin-preserved specimen from $6^{\circ} 26^{\prime}$ S., $39^{\circ} 44^{\prime}$ E. was examined. Sections were stained with Ehrlich's haematoxylin and eosin. Luminescent glands resembling, in general, those of Metridia were observed in the head and in abdominal segments 3 and 4 . Sacs of the glands are about $50 \times 200 \mu$ in size, and individual corpuscles are about $10 \times 30 \mu$.

Two kinds of glands are present: blue (type I), staining faintly with 
haematoxylin; and red (type 2), staining with eosin and showing striations and coarse granules. The two types of gland cells lie side by side.

Sewell (1929) has given details of cuticular pores in many copepods. In luminous species the position of some pores corresponds to luminous glands and these pores are probably the orifices through which the luminous glands discharge, but others are manifestly the openings of non-luminous skinglands.

\section{OBSERVATIONS ON MISCELLANEOUS PELAGIC ANIMALS}

Luminescence was observed in various pelagic animals, in addition to copepods, and some measurements of light intensities were made.

\section{Hydromedusae}

\section{COELENTERATES}

Aequorea macrodactyla (Brandt). Two specimens were caught at the surface in hand-nets, at station $\mathrm{Jy} 2,23.30 \mathrm{~h}$. When the animal was touched the margin of the umbrella luminesced. Light appeared in spots about the circumference, apparently in or near the tentacular bulbs. Only the immediate region that was stimulated flashed and there was no spread of luminescence from that locus to regions elsewhere around the margin. The light was seen best from below the umbrella.

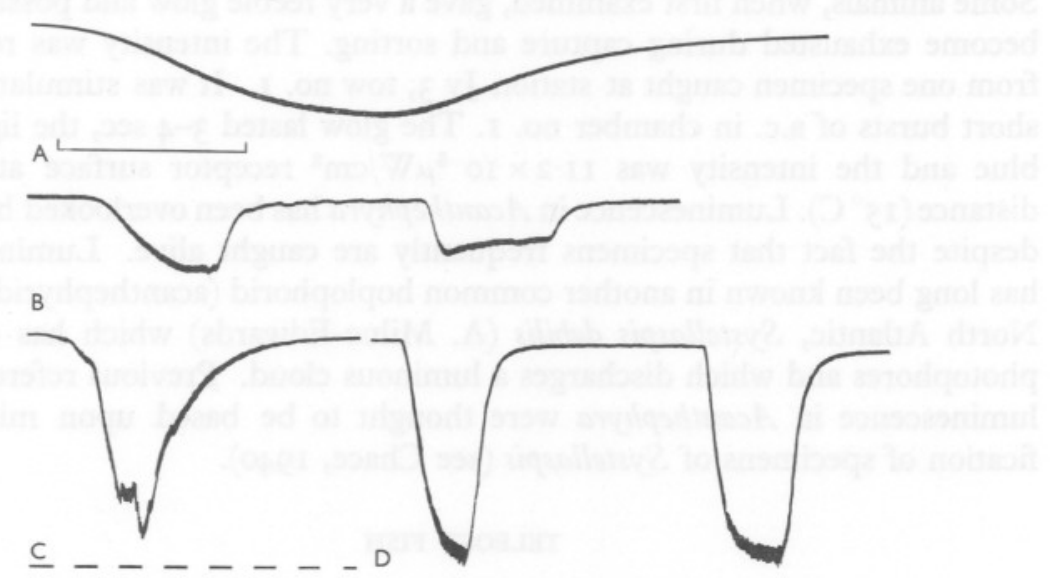

Text-fig. 6. Oscilloscope records (moving paper) of the luminous flashes of: A, Aeginura grimaldii; B, Periphylla periphylla; C, Meganyctiphanes norvegica; D, Myctophum punctatum. Flashing induced by short bursts of a.c. Time, horizontal bar (continuous line), I sec.

Aeginura grimaldii Maas. Two specimens from station Jy 3, tow no. I. The animals were stimulated with short pulses of a.c. in chamber no. 2. They responded with glows lasting $2-6 \mathrm{sec}$ (Text-fig. 6A). Intensities recorded 
were $0.5 \times 10^{-5}$ and $\mathrm{I} \cdot 3 \times 10^{-5} \mu \mathrm{W} / \mathrm{cm}^{2}$ receptor surface at $\mathrm{I} 5 \mathrm{~cm}$ distance $\left(15^{\circ} \mathrm{C}\right)$.

\section{Scyphomedusae}

Periphylla periphylla (Péron \& Lesueur). Two specimens from station Jy 3 , tow no. I. These were stimulated in chamber no. 2 with short pulses of a.c. They responded with glows lasting 0.8-4 sec and consisting of summated flashes (Text-fig. 6B). Intensities were $0.13 \times \mathrm{IO}^{-5}$ and $0.3 \times 10^{-5} \mu \mathrm{W} / \mathrm{cm}^{2}$ receptor surface at $15 \mathrm{~cm}$ distance $\left(15^{\circ} \mathrm{C}\right)$.

\section{Euphausiacea}

\section{CRUSTACEA}

Meganyctiphanes norvegicus (M. Sars). Two specimens from Station Jy 5. They were stimulated in chamber no. I with short pulses of a.c. (50-60 V). They gave rather prolonged feeble glows lasting 4-22 sec; intensities were $0.04 \times 10^{-5}$ and $0.13 \times 10^{-5} \mu \mathrm{W} / \mathrm{cm}^{2}$ receptor surface at $15 \mathrm{~cm}$ distance (Text-fig. 6c).

\section{Decapoda}

Acanthephyra pelagica (Risso). When handled these shrimp discharge a copious luminous secretion, the light from which persists for several seconds. With repeated stimulation the luminescence becomes weaker at each discharge. Some animals, when first examined, gave a very feeble glow and possibly had become exhausted during capture and sorting. The intensity was recorded from one specimen caught at station Jy 3, tow no. I. It was stimulated with short bursts of a.c. in chamber no. I. The glow lasted 3-4 sec, the light was blue and the intensity was $\mathrm{II} \cdot 2 \times \mathrm{IO}^{-5} \mu \mathrm{W} / \mathrm{cm}^{2}$ receptor surface at $\mathrm{I} 5 \mathrm{~cm}$ distance ( $15^{\circ} \mathrm{C}$ ). Luminescence in Acanthephyra has been overlooked hitherto, despite the fact that specimens frequently are caught alive. Luminescence has long been known in another common hoplophorid (acanthephyrid) of the North Atlantic, Systellaspis debilis (A. Milne-Edwards) which has discrete photophores and which discharges a luminous cloud. Previous references to luminescence in Acanthephyra were thought to be based upon misidentification of specimens of Systellaspis (see Chace, 1940).

\section{TELEOST FISH}

Mycotophum affine (Lütken) and $M$. punctatum Rafinesque. Two specimens were caught in hand-nets at station $\mathrm{Jy} 3,23.00 \mathrm{~h}$. They were attracted to the side of the ship by a lamp hanging in the water. The fish were stimulated with short bursts of a.c. $(80 \mathrm{~V})$ in chamber no. $\mathrm{I}$. They emitted a steady glow lasting $\mathrm{I} \cdot 3-4 \mathrm{sec}$ from all photophores during each stimulus (Text-fig. 6D). The intensity of the light of $M$. punctatum at $14 \mathrm{~cm}$ distance was $0 . \mathrm{I} \times 1 \mathrm{IO}^{-5} \mu \mathrm{W} / \mathrm{cm}^{2}$ receptor surface $\left(23^{\circ} \mathrm{C}\right)$. 


\section{DISCUSSION}

Subsequent to Giesbrecht's monographs on marine copepods (I892, I895), very little descriptive information concerning luminescence in this important group of planktonic Crustacea has been published. Much of the literature consists of casual observations of mixed plankton tows, often by workers with little knowledge of zooplankton taxonomy. Harvey (1952) lists nine families

TABLE 3. LUMINOUS COPEPODS

\begin{tabular}{|c|c|c|}
\hline Order and family & Species & $\begin{array}{c}\text { Source } \\
\text { (Literature reference or } \\
\text { original observation) }\end{array}$ \\
\hline \multicolumn{3}{|l|}{ Calanoida } \\
\hline Aetideidae & Chiridius obtusifrons G.O. Sars & Kiernik (1908) \\
\hline \multirow{9}{*}{ Metridiidae } & Lucicutia flavicornis (Claus) & Giesbrecht (1895) \\
\hline & $\begin{array}{l}\text { L. grandis (Giesbrecht) } \\
\text { Metridia lucens Boeck }\end{array}$ & $\begin{array}{l}\text { Original } \\
\text { Boeck (I864), } \\
\text { Kiernik (I908), } \\
\text { Bigelow (1926) }\end{array}$ \\
\hline & M. longa (Lubbock) & $\begin{array}{l}\text { Lilljeborg (1875), } \\
\text { Vanhöffen (1895), } \\
\text { Bigelow (1926) } \\
\text { Dahl (1894) }\end{array}$ \\
\hline & M. princeps Giesbrecht & Original \\
\hline & Pleuromamma spp. & Dahl, (1893, r894) \\
\hline & P. robusta (F. Dahl) & Original \\
\hline & P. abdominalis (Lubbock) & $\begin{array}{l}\text { Original } \\
\text { Giesbrecht (I } 895 \text { ) }\end{array}$ \\
\hline & P. gracilis (Claus) & Giesbrecht (1895) \\
\hline & Gaussia princeps (T. Scott) & $\begin{array}{l}\text { Personal communication, } \\
\text { W. Aron }\end{array}$ \\
\hline \multirow[t]{5}{*}{ Heterorhabdidae } & Heterorhabdus robustus Farran & Original \\
\hline & $\begin{array}{l}\text { H. papilliger (Claus) } \\
H \text {, norvegicus (Boeck) }\end{array}$ & $\begin{array}{l}\text { Giesbrecht (I895) } \\
\text { Original }\end{array}$ \\
\hline & Heterostylites longicornis (Giesbrecht) & Original \\
\hline & Hemirhabdus grimaldii (Richard) & Original \\
\hline & Disseta palumboi Giesbrecht & Original \\
\hline \multirow[t]{2}{*}{ Augaptilidae } & Euaugaptilus magnus (Wolfenden) & Original \\
\hline & & Original \\
\hline $\begin{array}{l}\text { Cyclopoida } \\
\text { Oncaeidae }\end{array}$ & Oncaea conifera Giesbrecht & Giesbrecht (1895) \\
\hline \multicolumn{3}{|c|}{ Doubtful records, all of which need confirmation before acceptance, are: } \\
\hline \multirow[t]{2}{*}{ Euchaetidae } & Euchaeta sp. & $\begin{array}{l}\text { Kiernik (1908), } \\
\text { Harvey (1952), } \\
\text { Hardy (1956) }\end{array}$ \\
\hline & Paraeuchaeta sp. & Hardy (1956) \\
\hline $\begin{array}{l}\text { Scholecithricidae } \\
\text { Phaennidae }\end{array}$ & $\begin{array}{l}\text { Scolecithricella sp. } \\
\text { Cephalophanes sp. }\end{array}$ & Hardy (1956) \\
\hline Pontellidae & $\begin{array}{l}\text { Cephalophanes sp. } \\
\text { Pontella sp. }\end{array}$ & $\begin{array}{l}\text { Sars, in Harvey }(1 \\
\text { Harvey (I952) }\end{array}$ \\
\hline
\end{tabular}

(one doubtful) containing luminescent representatives. On present evidence, we regard four of the families listed by Harvey as definitely luminous and add a fifth, the Augaptilidae (Table 3).

The sources for the identification of luminous species, so far as known, are given in Table 3. Only one copepod in the suborder Cyclopoida is reported to be luminous, viz. Oncaea conifera. Giesbrecht (1895) stated that several 
other species of Oncaea which he examined were not luminous. Giesbrecht's observations seem to be reliable. Only Kiernik (1908) has observed luminescence in Chiridius, and it would be well to have this observation confirmed; several other genera in the Aetideidae examined during the present investigation were not luminous. Other records of luminous copepods, for which there is reasonable doubt, are also presented in the lower part of Table 3. Euchaeta, according to Giesbrecht (I895), is not luminous, and confirmation of luminescence is desirable; Hardy (1956) seems to have assumed that Paraeuchaeta and Scolecithricella are luminous, and firm observations are wanting. In two other copepods, viz. Cephalophanes and Corycaeus mentioned by Harvey (1952), supposed luminescence is based upon tenuous conjecture: the peculiar eye of Cephalophanes has been misinterpreted as a luminous organ; Dana (I846) and Giesbrecht (I895) stated that Corycaeus was not luminous. We have been unable to find the source from which Harvey (1952) concluded that Pontella is luminous. Perhaps also there has been confusion with the large eyes of this species; moreover, Giesbrecht (I895) states that it is not luminous. The large eyes of Cephalophanes and Pontella are described by Vaissière (196I).

In the present study it has been shown that the luminescent glands of the Metridiidae, Lucicutiidae and Augaptilidae fluoresce, whereas those of the Heterorhabdidae do not. It is possible that, corresponding with this distinction, there are biochemical dissimilarities in the luminescent reactions of the Heterorhabdidae, compared with the other families. The Heterorhabdidae, moreover, show some physiological difference in their luminous responses to repetitive electrical stimulation. Further biophysical and biochemical studies of these several copepod families, in order to discover what differences exist in their luminescent systems, would be interesting.

Among the Metridiidae studied, each species possesses a peculiar pattern of fluorescence associated with the position of the luminescent glands. Giesbrecht (I895) also found striking differences in the disposition of luminescent glands between Pleuromamma abdominalis and P. gracile. However, from Giesbrecht's verbal description (1895) and illustration (1892, pl. 5, fig. 8) of P. abdominalis, it has not been possible to differentiate the luminous glands of that species from those of $P$. robusta (Text-fig. 4, p. 55I) studied by us. A more extensive survey of luminous copepods is desirable to establish whether the number and arrangement of luminescent glands can serve as useful taxonomic characters, particularly for identification of living animals. Some luminescent genera contain many species of rather similar appearance, which are presently separated by the detailed structure of appendages, not easily examined without dissection. For example, Metridia lucens and M. longa are quite similar in appearance, except for size, and under some conditions it is rather difficult to make a positive species-identification of living animals, yet the fluorescence patterns shown in Text-figs. 3 and 4 can be readily observed.

'Fluorescence taxonomy' may even have some use among species which do 
not have fluorescent luminescent glands. Two species, Heterorhabdus norvegicus and $H$. robustus, are not easily distinguished except by differences in the armature of the mouthparts. H. robustus, in particular, has a heavily chitinized spur on the left mandible, and this feature is frequently difficult to distinguish when partially obscured by the other mouth-parts. Yet the spur, as well as other dense chitinous structures, fluoresces strongly and can be recognized at once in ventral view when illuminated with ultra-violet light from above or below.

The discharge of a luminous secretion is well established in copepods; nevertheless, it has been observed that after repeated stimulation the response becomes weaker and appears to be entirely generated within the gland itself. Sometimes an after-glow of several seconds can be observed in a gland which has previously been stimulated several times. On one occasion only the portion nearest the external pore in a single luminescent gland on one of the swimming legs of $H$. norvegicus was seen to glow for several seconds after stimulation, although the entire gland seemed to be more or less homogeneous in appearance under natural illumination. In Heterorhabdus also the response was seldom synchronous (see also Fig. IG, p. 545). Under dark-field illumination multiple flashing was often noted on different parts of the head, and a progressive wave of flashing could sometimes be seen to move out into the first antennae.

With those animals which fluoresce under ultra-violet light repeated stimulation reduces the intensity of the response until only a dull glow is produced in the glands. At the same time the intensity of the fluorescence itself gradually diminishes, suggesting that fluorescence is associated with the photogenic material.

Unfortunately nothing is known about the biochemistry of luminescence in copepods, apart from Harvey's report (1926a) that he was unable to elicit a luciferin-luciferase reaction by the usual method. More refined techniques, however, may reveal the nature of the reactants, and the presence of two disparate kind of glands, in close juxtaposition, does suggest that two reactants are released that interact together in the sea water. The residual luminescence sometimes seen at the locus of the luminescent glands in the animal may occur in the necks of the glands, or in the cuticular pore where the reactants first encounter each other.

The very brief latencies of the luminous responses of Metridia and Pleuromamma demand some special explanation. It may be, for example, that the luminous response is initiated internally, before the secretion is expelled to the exterior. However, the usual response that one sees in fresh animals is associated with discharged secretion. It is not known how the material is discharged: gland cells themselves may be contractile, or raised hydrostatic pressure, produced by muscular contraction, may be involved.

Copepods emit a blue light, and previous physical measurements of 
M. lucens have revealed an emission peak at $482 \mathrm{~m} \mu$, and intensities up to $\mathrm{I} \cdot 2 \times \mathrm{IO}^{-3} \mu \mathrm{W}$ per square $\mathrm{cm}$ of receptor surface at $\mathrm{I} 8 \mathrm{~cm}$ distance (David \& Conover, 196I). In the present study the intensities of light emitted by all species of copepods examined ranged from $0.0 \mathrm{I} \times \mathrm{IO}^{-5}$ to $14.4 \times \mathrm{IO}^{-5} \mu \mathrm{W}$ per square $\mathrm{cm}$ of receptor surface at a distance of $15 \mathrm{~cm}$. Compared with other planktonic organisms, copepods emit bright flashes. The intensity of luminescence of copepods lies within the range recorded for other marine pelagic animals, and the brightest flashes equal those produced by euphausiids,
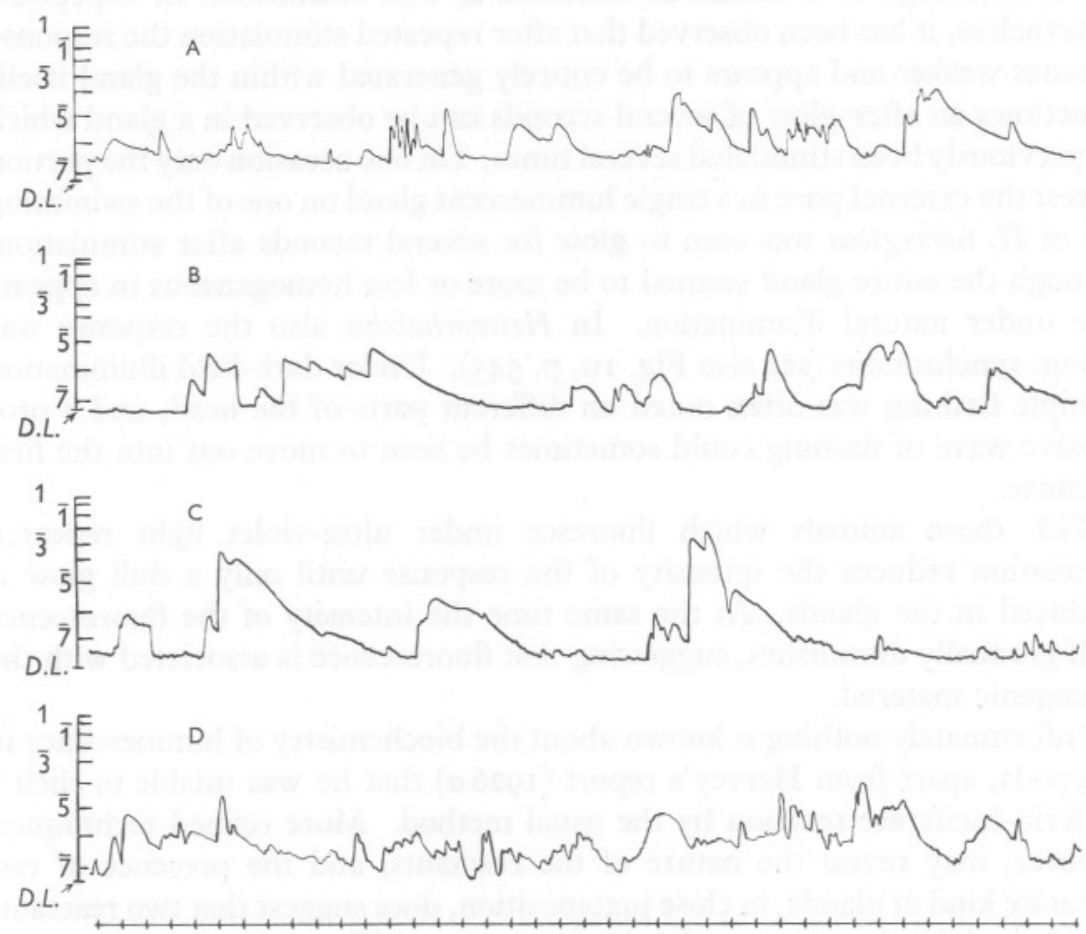

Text-fig. 7. Records of flashing of luminescent animals made with deep-sea photometer 27 July I96r, Station Jy 3, at: (A) 17.19 h, $550 \mathrm{~m}$; (B) I7.30 h, $800 \mathrm{~m}$; (C) $18.06 \mathrm{~h}, 2000 \mathrm{~m}$; (D) $23.00 \mathrm{~h}, 800 \mathrm{~m}$. A net haul to $975 \mathrm{~m}$ for animals used in laboratory tests was made at $\mathrm{I} 4.28-\mathrm{I} 6.00 \mathrm{~h}$. The presence of measurable daylight is shown between flashes in the record at $550 \mathrm{~m} \mathrm{(A),} \mathrm{but} \mathrm{not} \mathrm{in} \mathrm{the} \mathrm{other} \mathrm{records.} \mathrm{The} \mathrm{record} \mathrm{repeated} \mathrm{at} 800 \mathrm{~m}$ (D) at night indicates almost continuous flashing. Ordinates on vertical scales to left are $\log _{10}$ of intensities in $\mu \mathrm{W} / \mathrm{cm}^{2}$. DL, level of dark current. Vertical marks on line at bottom separate intervals of Isec.

acanthephyrids and pyrosomes. However, the total amount of light produced by copepods may be much less than in some of these other animals mentioned because the response is usually rather brief. There is little doubt that a great deal of luminescence in the mid-waters of the ocean is due to copepods, such as Metridia and Pleuromamma, which execute diurnal movements, moving 
towards the surface at night. Text-fig. 7 contains records made with a submerged bathyphotometer (Clarke \& Wertheim, 1956), at depths of 550$2000 \mathrm{~m}$ at station Jy 3 and illustrates some patterns of flashing frequently observed with this instrument. Such flashes are not unlike those produced by copepods, and it is hoped that future work will render it possible to identify the organisms responsible for the luminous flashes that can now be detected in the sea.

David \& Conover (I96I) have indicated that the luminous response of copepods forms part of an escape reaction. In this behaviour a rapid luminous response, having a brief latency and fast increment of light intensity, would be of value. It is probably analogous to the luminous discharges of decapod crustaceans (e.g. Acanthephyra), squid (Heteroteuthis), and fish (Searsia): such discharges, in dark environments, appear to detract momentarily the attention of some other animal while the creature making them escapes quickly. Copepods, like decapod Crustacea, have quick escape reactions, probably mediated by giant axons (Lowe, 1935; Holmes, 1942).

We should like to thank Dr P. L. Sachs and Mr N. R. Andersen for collecting luminous copepods for us on R.V. 'Crawford' on 7 September I96I, and Dr S. M. Marshall for securing live Metridia lucens at Millport and sending them to Plymouth. Mr G. H. Volkmann loaned us a cathode-ray oscilloscope; Dr K. S. Tweedell, and Messrs R. C. Kahn and G. C. Whiteley helped us with fluorescence microscopy; Mr T. R. Renshaw and Miss J. R. Beebe rendered general assistance. Mr A. C. G. Best prepared the histological sections and made the photomicrographs. Mr J. H. Wickstead loaned us his sections of Gaussia princeps for examination.

Animals were identified by Dr F. S. Russell (medusae), Dr G. D. Grice (copepods), Dr Fenner A. Chace, Jr. (acanthephyrid), Dr N. B. Marshall (myctophids).

One of us (J.A.C.N.) acknowledges receipt of a fellowship from the Woods Hole Oceanographic Institution and should like to thank the Director of that Institution and his staff for many kindnesses.

\section{SUMMARY}

A comparative study of the following luminous copepods was undertaken: Metridia lucens, M. longa, M. princeps, Pleuromamma robusta, P. xiphias, Heterorhabdus norvegicus, H. robustus, Heterostylites longicornis, Lucicutia grandis, Hemirhabdus grimaldii, Disseta palumboi, Euaugaptilus magnus and Centraugaptilus horridus. Flashes produced by electrical stimulation (a.c. or condenser shocks) and mechanical stimulation were recorded photoelectrically. Flashes lasted from 2 to $37 \mathrm{sec}$. Latencies of some species (Metridiidae), following electrical stimulation, were very short, 7-9 msec. Intensities ranged from $0.02 \times 10^{-5}$ to $14.4 \times 10^{-5} \mu \mathrm{W} / \mathrm{s} \mathrm{cm}^{2}$ of receptor surface at $15 \mathrm{~cm}$ distance 
$\left(0.0045 \times 10^{-2}\right.$ to $3.24 \times 10^{-2} \mu \mathrm{W} / \mathrm{cm}^{2}$ at $\left.\mathrm{I} \mathrm{cm}\right)\left(10-20^{\circ} \mathrm{C}\right)$. Luminous glands of Metridiidae, Lucicutiidae and Augaptilidae are autofluorescent; the location of the luminous glands in these families and in Heterorhabdidae is described. Two kinds of glandular cells (types I and 2) occur in the luminescent areas. The cells are large saccular structures containing granular or homogeneous material, and are distinguished by staining peculiarities. Cell types I and 2 open through common pores, and may be the source of luminous reactants. Some measurements of luminescence in other pelagic animals are presented, for comparison with copepods, viz. Aequorea macrodactyla, Aeginura grimaldii (Hydromedusae), Periphylla periphylla (Scyphomedusa), Meganyctiphanes norvegica and Acanthephyra pelagica (Crustacea), Myctophum punctatum (Teleostei). Our present knowledge regarding luminescence among copepods is reviewed.

\section{REFERENCES}

BAIRD, W., I843. Note on the luminous appearance of the sea, with descriptions of some of the entomostracous insects by which it is occasioned. Zoologist, Vol. I, pp. 55-6r.

Bigelow, H. B., I926. Plankton of the offshore waters of the Gulf of Maine. Bull. U.S. Bur. Fish., Vol. 40, 509 pp.

BoECK, A., I864. Oversigt over de ved Norges Kyster jagttag Copepoder, henhörende til Calanidernes, Cyclopidernes og Harpactidernes Familier. Forh. VidenskSelsk. Krist., Bd. 7, pp. 226-82.

BUCK, J. \& CASE, J. F., I96r. Control of flashing in fireflies. I. The lantern as a neuroeffector organ. Biol. Bull., Woods Hole, Vol. I21, pp. 234-56.

ChACE, F. A., JR., 1940. Plankton of the Bermuda Oceanographic Expeditions. IX. The bathypelagic Caridean Crustacea. Zoologica, N.Y., Vol. 25, pp. II7-209.

Chang, J. J., 1954. Analysis of the luminescent response of the ctenophore, Mnemiopsis leidyi, to stimulation. F. cell. comp. Physiol., Vol 44, pp. 365-94.

ClaRKe, G. L. \& BRESLAU, L. R., 1959. Measurements of bioluminescence off Monaco and Northern Corsica. Bull. Inst. océanogr. Monaco, No. I I47, 3 I pp.

- 1960. Studies of luminescent flashing in Phosphorescent Bay, Puerto Rico, and in the Gulf of Naples using a portable bathyphotometer. Bull. Inst. océanogr. Monaco, No. II7I, 32 pp.

Clarke, G. L. \& Denton, E. J., 1962. Light and animal life. The Sea: Ideas and Observations, Sec. 4, ch. IO, pp. 456-68. London: Interscience Publishers.

Clarke, G. L. \& HubBard, C. J., 1959. Quantitative records of the luminescent flashing of oceanic animals at great depths. Limnol. \& Oceanogr., Vol. 4, pp. $163-80$.

Clarke, H. L. \& Wertheim, G. K., I956. Measurements of illumination at great depths and at night in the Atlantic Ocean by means of a new bathyphotometer. Deep-sea Res., Vol. 3, pp. 189-205.

Conover, R. J., 1960. The feeding behavior and respiration of some marine planktonic crustacea. Biol. Bull., Woods Hole, Vol. r I9, pp. 399-415.

DAHL, F., I893. Pleuromamma, ein Krebs mit Leuchtorgan. Zool. Anz., Bd. 16, pp. 104-9.

- I894. Leuchtende Copepoden. Zool. Anz., Bd. 17, pp. I0-13.

Dana, J. D., I846. Notice of some genera of Cyclopacea. Ann. Mag. nat. Hist., Vol. I8, pp. I8I-5. 
DAvid, C. N. \& Conover, R. J., I96r. Preliminary investigation on the physiology and ecology of luminescence in the copepod, Metridia lucens. Biol. Bull., Woods Hole, Vol. I21, pp. 92-107.

GIESBRECHT, W., I892. Systematik und Faunistik der pelagischen Copepoden des Golfes von Neapel und der angrenzenden Meeres-Abschnitte. Fauna u. Flora Neapel, Bd. 19, 83I pp. Atlas, 54I Tafeln.

- 1895. Mittheilungen über Copepoden. 8. Über das Leuchten der pelagischen Copepoden und das tierische Leuchten im Allgemeinen. Mitt. zool. Sta. Neapel, Bd. II, pp. $648-89$.

Hardy, A. C., 1956. The Open Sea: Its Natural History: The World of Plankton. 355 pp. London: Collins.

HARVEY, E. N., I926a. Additional data on the specificity of luciferin and luciferase, together with a general survey of this reaction. Amer. F. Physiol., Vol. 77, pp. $548-54$.

- 1926b. Bioluminescence and fluorescence in the living world. Amer. F. Physiol., Vol. 77, pp. 555-6r.

1952. Bioluminescence. 649 pp. New York: Academic Press.

Holmes, W., I942. The giant myelinated nerve fibres of the prawn. Phil. Trans. B, Vol. 23I, pp. 293-3II.

KIERNIK, E., I908. UUber einige bisher unbekannte Tiere. Zool. Anz., Bd. 33, pp. 37680.

LILLEJEBORG, W., I875. De under Svenska vetenskapliga expeditionen till Spetsbergen I872-1873 derstädes samlade Hafs-Entomostraceer. Öfvers. VetenskAkad. Forh., Stockh., Aår 1875, No. 4, pp. 3-12.

LowE, E., I935. On the anatomy of a marine copepod, Calanus finmarchicus (Gunnerus). Trans. roy. Soc. Edinb., Vol. 58, pp. 561-603.

Sewell, R. B. S., I929. The Copepods of Indian Seas. Calanoida. Mem. Indian Mus., Vol. IO, 22I pp.

SteEdman, H. F., I960. Ester wax 1960: a histological embedding medium. Quart. F. micr. Sci., Vol. Ior, pp. 459-62.

VAIssiÉRE, R., I96I. Morphologie et histologie comparées des yeux des Crustacés Copépodes. Arch. Zool. exp. gén., T. I00, pp. I-I26.

VANHÖFfEN, E., I895. Das Leuchten von Metridia longa Lubb. Zool. Anz., Bd. I8, pp. 304-5.

\section{EXPLANATION OF PLATES}

Plate I

Photomicrograph of Metridia lucens exposed to ultra-violet light from below. Luminous areas and exoskeleton were autofluorescent. Luminous glands show as white patches on the head, second thoracic segment, and abdomen. The abdomen gave a muscular spasm during exposure. $\times 63$. (Photograph by A. C. G. Best.)

\section{Plate II}

Luminous glands of M. longa. Helly's fluid. Heidenhain-azan. Fig. I. Longitudinal vertical section through middle of head. $\times 192$. Fig. 2. Longitudinal horizontal section through head. $\times 789 . \mathrm{I}$, gland type $\mathrm{I} ; 2$, gland type $2 ; p$, pore. 


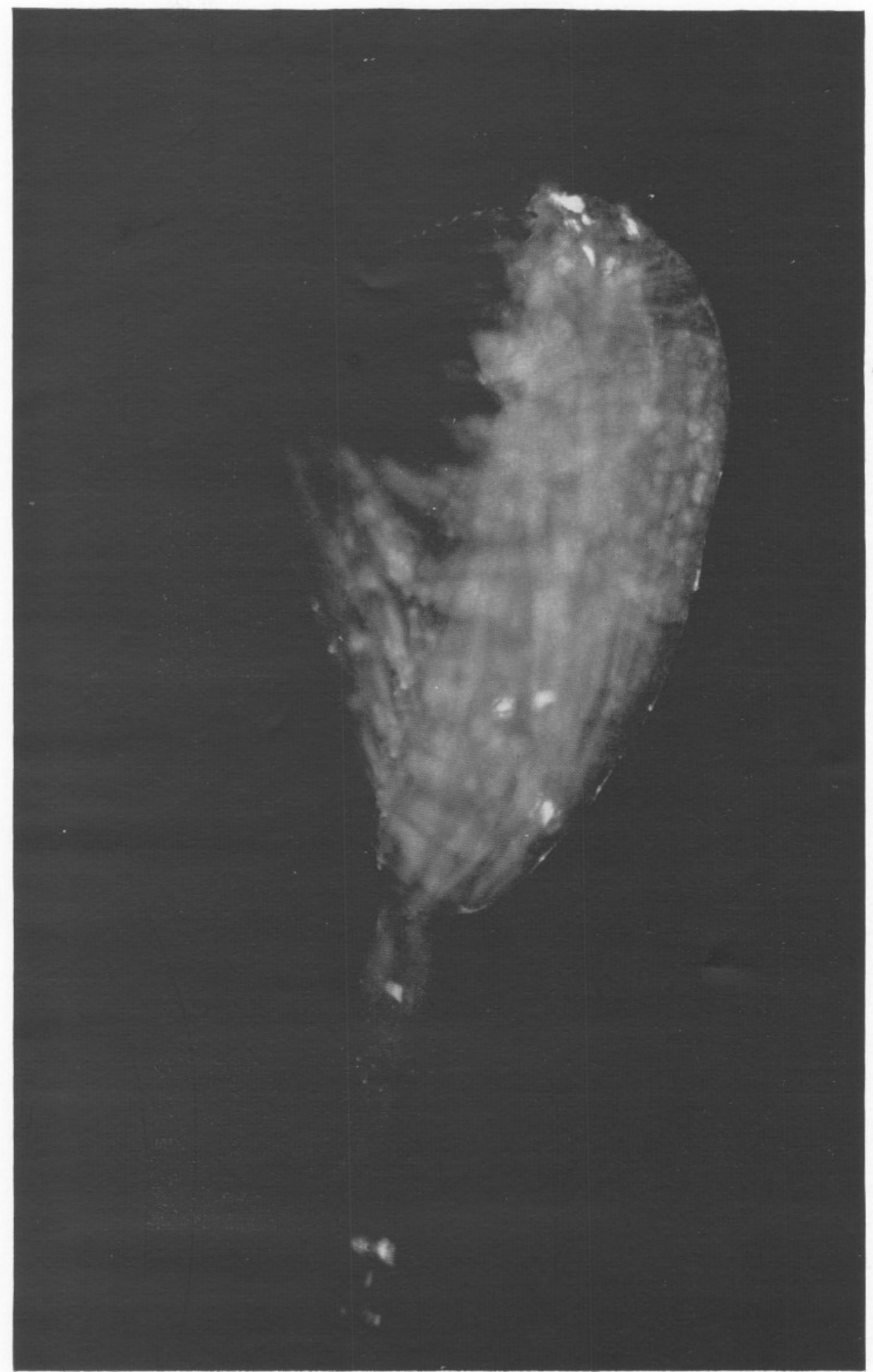

(Facing p. 564) 

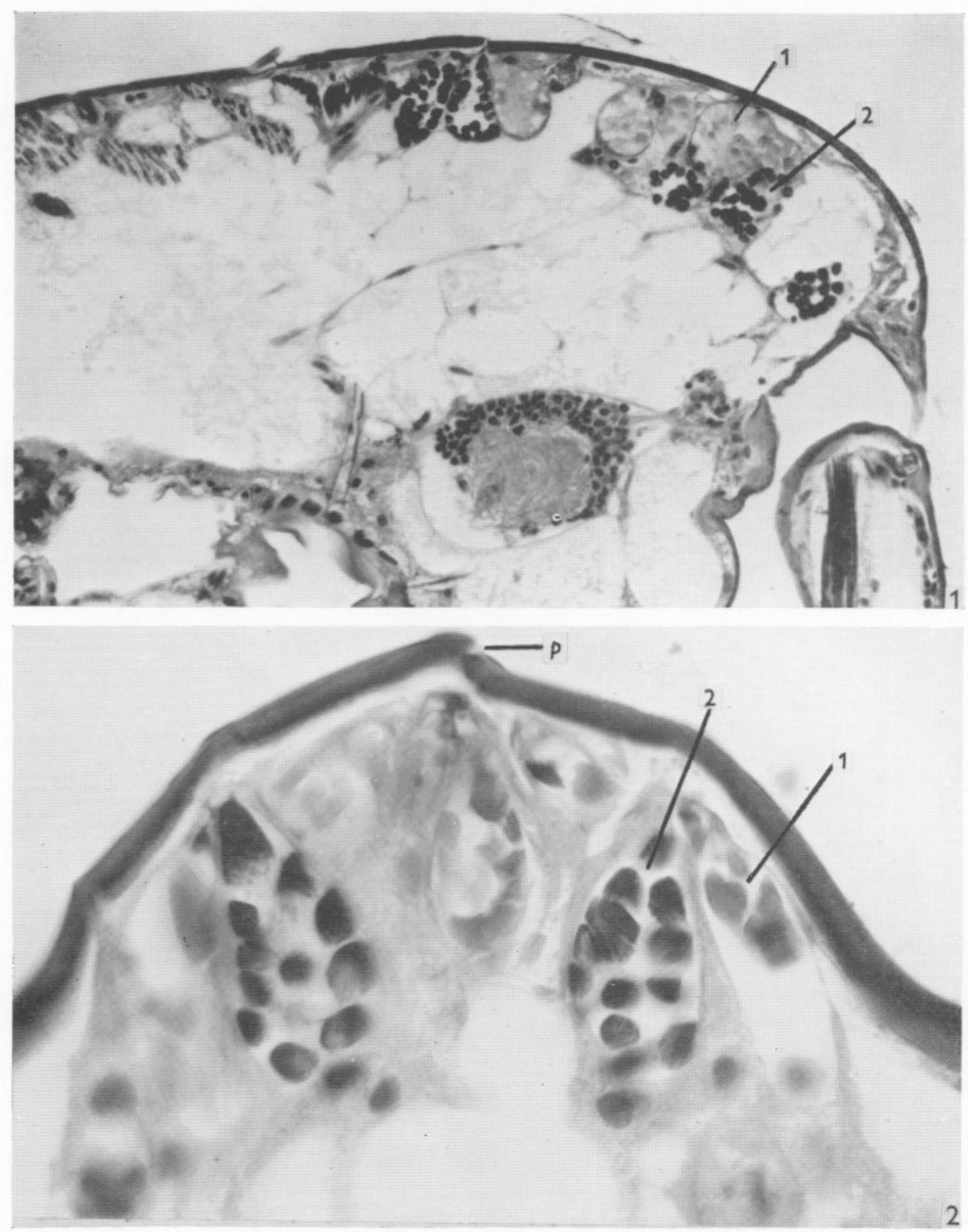